\title{
Narrative review: pengaruh terapi massage counterpressure terhadap pengurangan nyeri dalam persalinan
}

\author{
Hutari Puji Astuti a,b,", Andari Wuri Astuti b, Dinar Agustin'b, Hardiyanti Fitrah \\ Awaliyahb, Gana RendraWinartib, Vanny Oktaviani Jaya ${ }^{b}$ \\ a Universitas Kusuma Husada Surakarta, Surakarta, Jawa Tengah, 57136, Indonesia; \\ b UniversitasAisyiyah Yogyakarta, Sleman, Yogyakarta. 55292, Indonesia; \\ 1hutaripujiastuti95@gmail.com; 2astutiandari@unisayogya.ac.id; ${ }^{3}$ Agustindinar40@gmail.com; \\ 4hardiyanti.awaliyah@gmail.com; ${ }^{5}$ ganarendra1311@gmail.com; ${ }^{4}$ vannyoktaviani1610@gmail.com \\ *Correspondent Author
}

\section{ARTICLE INFO}

Article history

Received: $28-7-2021$

Revised : 23-8-2021

Accepted: $3-9-2021$

Keywords

Narative review, Massage

Counterpressure, Labor pain

\section{ABSTRACT}

Labor often prompts an unpleasant, fearful, or, further, traumatic experiences due to the pain it entails. Scientific evidence suggests that pain during labor can be managed using two methods; pharmacological and non-pharmacological. Pharmacology is a method of using drugs, whereas non-pharmacologic is without the administration of drugs. Nonpharmacological method is known as complementary and alternative therapies, one practice is through massage. Massage frequently performed to reduce labor pain is counterpressure. The purpose of this study is to investigate the effect of counterpressure massage therapy as a measure to reduce labor pain. The method used is a narrative review. Article exploration was carried out in several databases, which are Pubmed and Science Direct. In the case of Gray Literature, it was accessed via Google Scholar. Specific keywords were employed for literature search and articles were selected by considering inclusion and exclusion criteria. The article selection process was elaborated transparently in the PRISMA Flowchart. From the article selection procedure, 14 articles were identified and fulfilled the criteria. Thus, articles were critically analyzed (Critical Appraisal) using the Mixed Method Appraisal Tool (MMAT). The review concludes that counterpressure is a massage performed by applying continuous pressure to the patient's sacral with the heel of the hand or fist of the hand. Counterpressure massage can be done in a straight stroke or small circular stroke. This technique is proven to be sufficient in relieving back pain during labor. The recommendation suggested is based on the 14 articles reviews carried out that a common problem occurring in laboring women is physiological pain experience during childbirth so that it may provoke bad experiences for mothers, especially fear and anxiety that may lead to prolonged labor.

This is an open-access article under the CC-BY-SA license.

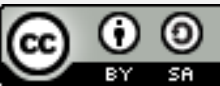

\section{Pendahuluan}

Persalinan adalah proses fisiologis yang harus dialami oleh setiap wanita yang hamil. Proses ini seringkali menjadi periode yang sangat dinanti-nantikan oleh ibu hamil (1). Akan tetapi persalinan juga membawa konsekuensi rasa nyeri yang menimbulkan rasa cemas dan takut. Saat ibu akan melahirkan, biasanya ia membutuhkan dukungan terus menerus dari bidan dan menuntut asuhan kebidanan yang kompleks sehingga terbina hubungan antara ibu dan bidan dengan baik, hal ini bisa mengurangi rasa cemas atau takut karena nyeri persalinan 
(2). Nyeri persalinan dapat menimbulkan stres yang menyebabkan pelepasan hormon yang berlebihan seperti katekolamin dan steroid. (3).

Nyeri pada saat persalinan dapat diatasi dengan dua metode yaitu farmakologi dan nonfarmakologi. Metodefarmakologi merupakan metode menggunakan obat yang dapat mengurangi nyeri, sedangkan metode nonfarmakalogi atau tanpa obat juga dapat membantu mengurangi rasa nyeri. Teknik ini juga dikenal sebagai terapi komplementer dan salah satu alternatifnya adalah massage (4). Massage yang sering digunakan untuk mengurangi nyeri persalinan yaitu counturpressure. Massage couterpressure adalah melakukan massage dengan penekanan yang cukup kuat pada titik tertentu dipunggung bawah selama kontraksi (5).

Teknik Counterpressure akan menyebabkan pemblokiran impuls nyeri yang akan ditramisikan ke otak lebih cepat (6). Hal ini sangat membantu dalam mengurangi nyeri yang dirasakan, karena penekanan pada panggul dapat mengurangi regangan yang terjadi pada sakro iliaka sehingga mengurangi tegangan yang terjadi akibat penekanan internal dari kepala janin (7). Pemberian terapi masase dengan teknik Counterpressure dapat menghambat rasa nyeri yang dihantarkan menuju medulla spinalis dan otak, selain itu tekanan dengan teknik ini mengaktifkan endhorpine, sehingga aliran rasa nyeri dapat dihambat (8).

Akupresur berguna untuk bermacam-macam sakit dan nyeri serta mengurangi ketegangan, kelelahan, dan penyakit. Dalam persalinan kala I akupresur dapat digunakan ketika kontraksi terasa nyeri (9). Nyeri ini muncul ketika terjadi blokade arus energi sepanjang meridian tertentu dalam tubuh. Blokade yang dilepaskan melalui teknik akupresur, keserasian dan fungsi halus akan dikembalikan (10). Akupresur memiliki keunggulan atau kelebihan dibandingkan dengan teknik atau metode lainnya. Akupresur sangat praktis karena tidak memerlukan banyak alat dan cukup dengan jari tangan, ibu jari, telunjuk, telapak tangan serta murah dan aman (11). Tujuan studi ini adalah untuk mengetahui pengaruh, efektivitas dan hambatan terapi massage counterpressure terhadap pengurangan nyeri dalam persalinan melalui metode narative review.

\section{Metode}

Studi ini merupakan suatu narrative review. Pelaksanaan penelitian ini dilakukan pada bulan Juni - Juli 2021 selama dua bulan. Adapun langkah-lanGkah narrative review adalah dengan menentukan topik dan pertanyaan review, mencari literatur secara efektif, menyeleksi literature sesuai kriteria inklusi dan eksklusi, melakukan charting data, melakukan critical appraisal dan melaporkan hasil review (12).

Dalam penelitian ini pertanyaan review yang telah ditetapkan adalah "Bagaimana pengaruh pemberian terapi massage counterpressure pada ibu bersalin dalam pengurangan rasa nyeri persalinan?" Setalah menentukan pertanyaan review, dilakukan pencarian literartur melalui beberapa data bases yaitu Pubmed dan Science Direct, dan untuk Grey Literatur diakses melalui Google Scholar. Proses pencarian kata kunci menggunakan keywords, boolean srategi, dan truncation.

Keywords yang digunakan adalah"maternity*OR mother* OR mom* OR women* AND massage counterpressure* AND labor pain* delivery pain* OR childbirth pain* OR birth pain*". Seleksi dari artikel menggunakan kriteria inklusi dan eksklusi. Kriteria inklusinya yaitu artikel yang terbit dalam jurnal nasional dan internasional. Artikel yang digunakan diterbitkan mulai tahun 2016 sampai dengan 2021. Sedangkan kriteria eksklusinya adalah opinion papers, review papers, commentary, ulasan buku, artikel yang membahas tentang terapi massage counterpressure pada ibu hamil dan ibu nifas.

Proses seleksi secara trasnparan bisa dilihat dalam PRISMA flowchart sebagai berikut: 

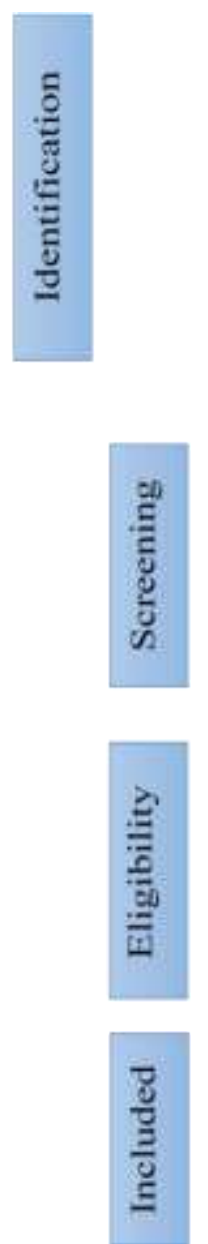
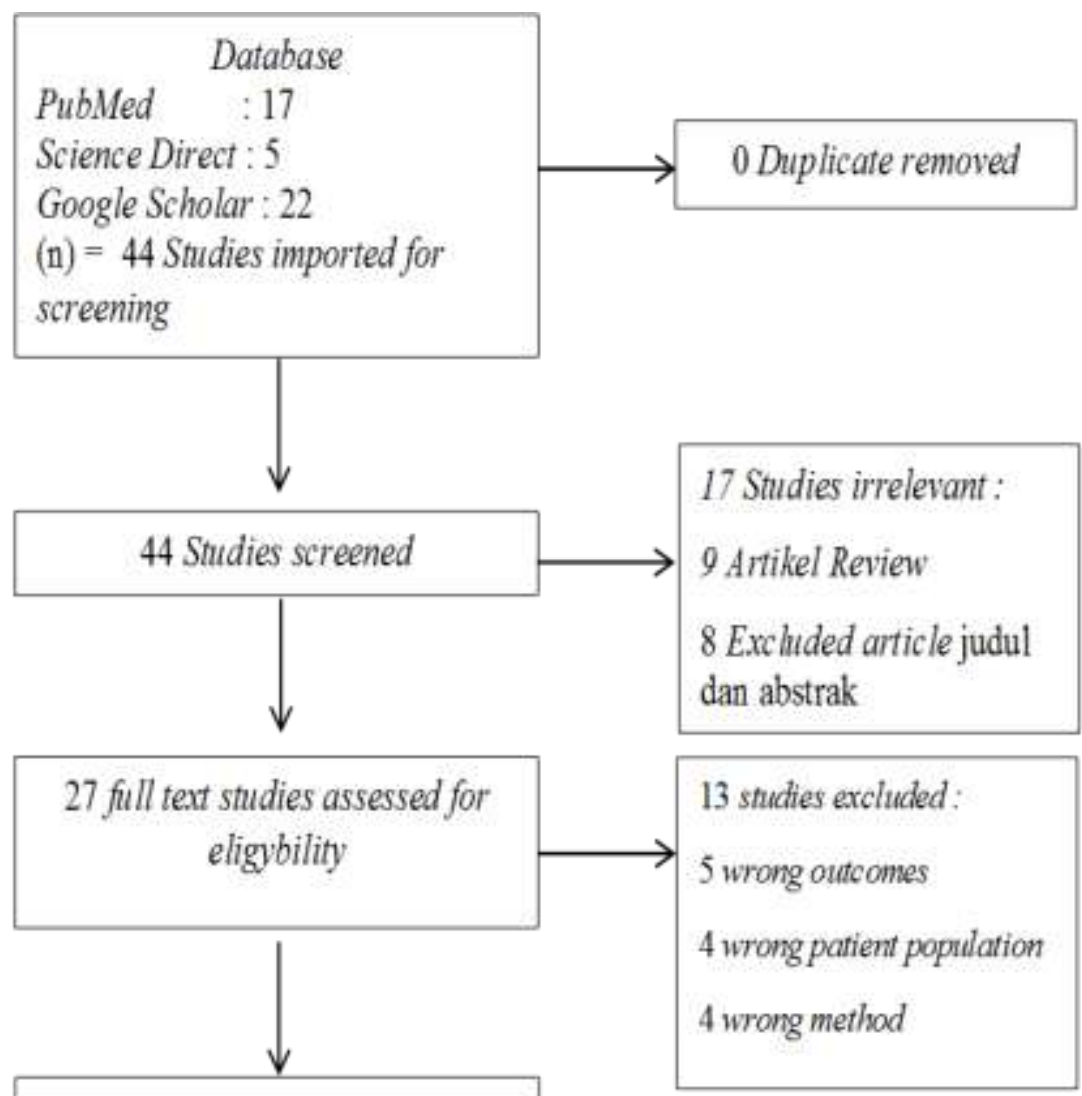

Gambar 1. PRISMA flow chart

Setelah melakukan pemilihan studi, untuk mengetahui kualitas artikel yang telah dipilih, maka dilakukan critical appraisal. Critical Appraisal dalam penelitian ini menggunakan Mixed Method Appraisal Tool (MMAT). MMAT dirancang untuk menilai kualitas metodologi suatu studi dari lima kategori penelitian yakni, penelitian kualitatif, randomized controlled trials, studi non-randomized, studi deskriptif kuantitatif dan studi mixed-method (13).

Pada tahap ini terdapat 14 artikel yang sesuai dengan topik dan kriteria inklusi yang sudah ditetapkan, ada beberpa study design yang digunakan diantaranya Randomized Control Trial, Quantitative non-randomized, dan Mixed Method Setiap metode penelitian memiliki cheklist critical appraisal yang tidak sama. Untuk penilaian kualitas artikel yang masuk dalam tahap ini, penulis menggunakan skala grade A, B, dan C untuk membedakan kategori artikel yang termasuk dalam kategori BAIK (grade A), CUKUP BAIK (grade B), dan KURANG BAIK (grade C).

Dari 14 artikel yang dilakukan proses critical appraisal didapatkan hasil bahwa artikel yang dinilai masuk kedalam grade A sejumlah 10 buah artikel, dan grade B sejumlah 4 buah artikel. Critical appraisal menggunakan MMAT bisa dilihat dalam tabel MMAT berikut: 
Tabel 1. MMAT Critical Appraisal Checklist for Non Randomize Control Trial Study

\begin{tabular}{clccccc}
\hline No & \multicolumn{1}{c}{ Elemen Penilaian } & A1 & A2 & A3 & A8 & A12 \\
\hline 1 & Apakah pertanyaan penelitian jelas? & 2 & 2 & 2 & 1 & 2 \\
\hline 2 & $\begin{array}{l}\text { Apakah data yang dikumpulkan mampu } \\
\text { menjawab pertanyaan penelitian? }\end{array}$ & 2 & 2 & 2 & 2 & 2 \\
\hline 3 & $\begin{array}{l}\text { Apakah partisipan mewakili populasi } \\
\text { target? }\end{array}$ & 2 & 2 & 2 & 2 & 2 \\
\hline 4 & $\begin{array}{l}\text { Apakah pengukurannya sesuai dengan } \\
\text { luaran dan intervensi (atau paparan)? }\end{array}$ & 2 & 1 & 2 & 2 & 2 \\
\hline 5 & $\begin{array}{l}\text { Adakah luaran data yang lengkap dari studi } \\
\text { tersebut? }\end{array}$ & 1 & 0 & 0 & 0 & 0 \\
\hline 6 & $\begin{array}{l}\text { Apakah variable pengganggu } \\
\text { diperhitungkan dalam desain dan Analisa? }\end{array}$ & 1 & 0 & 0 & 0 & 0 \\
\hline 7 & $\begin{array}{l}\text { Selama masa penelitian, apakah intervensi } \\
\text { dilakukan (atau terjadi paparan) seperti } \\
\text { yang diharapkan? }\end{array}$ & 2 & 2 & 2 & 1 & 1 \\
\hline$\quad$ Total Nilai/Grade & $\mathbf{1 2 / A}$ & $\mathbf{9 / B}$ & $\mathbf{1 0 / A}$ & $\mathbf{8 / B}$ & $\mathbf{9 / B}$ \\
\hline & & & & &
\end{tabular}

Tabel 2. MMAT Critical Appraisal Checklist for Non Randomize Control Trial Study

\begin{tabular}{|c|c|c|c|c|c|c|}
\hline No & Elemen Penilaian & A4 & A5 & A9 & A10 & A14 \\
\hline 1 & Apakah pertanyaan penelitian jelas? & 2 & 2 & 1 & 2 & 2 \\
\hline 2 & $\begin{array}{l}\text { Apakah data yang dikumpulkan } \\
\text { mampu menjawab pertanyaan } \\
\text { penelitian? }\end{array}$ & 2 & 2 & 1 & 2 & 2 \\
\hline 3 & $\begin{array}{l}\text { Apakah partisipan mewakili populasi } \\
\text { target? }\end{array}$ & 2 & 2 & 2 & 2 & 2 \\
\hline 4 & $\begin{array}{l}\text { Apakah pengukurannya sesuai dengan } \\
\text { luaran dan intervensi (atau paparan)? }\end{array}$ & 2 & 2 & 2 & 2 & 2 \\
\hline 5 & $\begin{array}{l}\text { Adakah luaran data yang lengkap dari } \\
\text { studi tersebut? }\end{array}$ & 2 & 2 & 0 & 2 & 1 \\
\hline 6 & $\begin{array}{l}\text { Apakah variable pengganggu } \\
\text { diperhitungkan dalam desain dan } \\
\text { Analisa? }\end{array}$ & 0 & 0 & 0 & 0 & 0 \\
\hline \multirow[t]{2}{*}{7} & $\begin{array}{l}\text { Selama masa penelitian, apakah } \\
\text { intervensi dilakukan (atau terjadi } \\
\text { paparan) seperti yang diharapkan? }\end{array}$ & 2 & 2 & 2 & 2 & 2 \\
\hline & Total Nilai/Grade & $\begin{array}{c}12 / \\
\mathrm{A}\end{array}$ & $\begin{array}{c}12 / \\
\text { A }\end{array}$ & 8/B & $\begin{array}{c}12 / \\
\mathrm{A}\end{array}$ & $\begin{array}{c}11 / \\
\mathbf{A}\end{array}$ \\
\hline
\end{tabular}


Tabel 3. MMAT Critical Appraisal Checklist for Randomize Control Trial Study

\begin{tabular}{clccc}
\hline No & \multicolumn{1}{c}{ Elemen Penilaian } & A6 & A7 & A13 \\
\hline 1 & Apakahpertanyaanpenelitiannyajelas? & 2 & 2 & 2 \\
\hline 2 & $\begin{array}{l}\text { Apakah data yang dikumpulkan mampu menjawab } \\
\text { pertanyaan penelitian? }\end{array}$ & 2 & 2 & 2 \\
\hline 3 & $\begin{array}{l}\text { Apakah pengacakan/ randomisasi dilakukan secara } \\
\text { tepat? }\end{array}$ & 2 & 2 & 2 \\
\hline 4 & $\begin{array}{l}\text { Apakah ada perbandingan antar kelompok sejak } \\
\text { awal/ periode tertentu? }\end{array}$ & 2 & 2 & 2 \\
\hline 5 & Adakah luaran data yang lengkap dari studi tersebut? & 2 & 2 & 2 \\
\hline 6 & $\begin{array}{l}\text { Apakah penilai hasil tidak mengetahui intervensi } \\
\text { yang diberikan? }\end{array}$ & 2 & 2 & 2 \\
\hline 7 & Apakah peserta mematuhi intervensi yang diberikan? & 2 & 2 & 2 \\
\hline & Total Nilai/Grade & $\mathbf{1 4 /}$ & $\mathbf{1 4 /}$ & $\mathbf{1 4 /}$ \\
& $\mathbf{A}$ & $\mathbf{A}$ & $\mathbf{A}$ \\
\hline & & &
\end{tabular}

Tabel 4. MMAT Critical Appraisal Checklist for Mixed Method

\begin{tabular}{clc}
\hline No & \multicolumn{1}{c}{ Elemen Penilaian } & $\begin{array}{c}\text { A/1 } \\
\mathbf{1}\end{array}$ \\
\hline 1 & Apakah pertanyaan penelitiannya jelas? & 2 \\
\hline 2 & $\begin{array}{l}\text { Apakah data yang dikumpulkan mampu menjawab pertanyaan } \\
\text { penelitian? }\end{array}$ & 2 \\
\hline 3 & $\begin{array}{l}\text { Apakah ada alasan yang cukup menggunakan desain mixed- } \\
\text { method untuk menjawab pertanyaan penelitian? }\end{array}$ & 1 \\
\hline 4 & $\begin{array}{l}\text { Apakah komponen penelitian yang berbeda secara efektif mampu } \\
\text { menjawab pertanyaan penelitian? }\end{array}$ & 1 \\
\hline 5 & $\begin{array}{l}\text { Apakah hasil temuan dari integrasi antara studi kuantitatif dan } \\
\text { kualitatif diinterpretasikan secara memadai? }\end{array}$ & 1 \\
\hline 6 & $\begin{array}{l}\text { Apakah divergensi dan inkonsistensi antara hasil kuantitatif dan } \\
\text { kualitatif telah dapat ditangani dengan memadai? }\end{array}$ & 1 \\
\hline 7 & $\begin{array}{l}\text { Apakah komponen studi yang berbeda mematuhi kriteria kualitas } \\
\text { dari masing masing metode yang terlibat? }\end{array}$ & 2 \\
\hline & $\quad$ Total Nilai/Grade & $\mathbf{1 0 /}$ \\
\hline
\end{tabular}


3. Hasil dan Pembahasan

3.1 Karakteristik Studi

3.1.1 Karakteristik studi berdasarkan negara

Artikel yang telah didapatkan, berasal dari penelitian yang dilakukan di beberapa negara, yaitu negara berkembang yang meliputi Benua Asia, Eropa dan Amerika. Penelitian di Benua Asia terdapat 11 artikel dari Negara Indonesia dan 1 artikel dari Negara Iran. Penelitian di Benua Eropa hanya 1 artikel dari Negara Turki dan Penelitian di Benua Amerika juga hanya 1 artikel dari Negara Brazil.

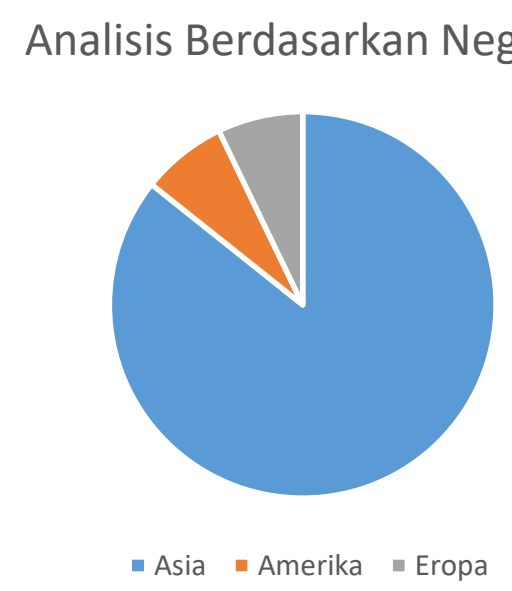

Gambar 2. Analisis Berdasarkan Negara

3.1.2 Karakteristik studi berdasarkan jenis studi

Hasil dari 14 artikel yang telah didapatkan dan telah terpilih sesuai dengan kualitas terbaik, selanjutnya dilakukan proses ekstraksi data dengan menggolongkan beberapa poin dari artikel misalnya tujuan penelitian, desain penelitian, jumlah sample dan hasil dari penelitian tersebut. Dari sebanyak 14 artikel yang terpilih didapatkan hasil bahwa penelitian tersebut menggunakan studi Randomize Control Trial sebanyak 3 artikel, studi Non Randomize Control Trial sebanyak 10 artikel dan studi Mixed Method sebanyak 1 artikel .

\section{Analisis Berdasarkan Jenis Studi}

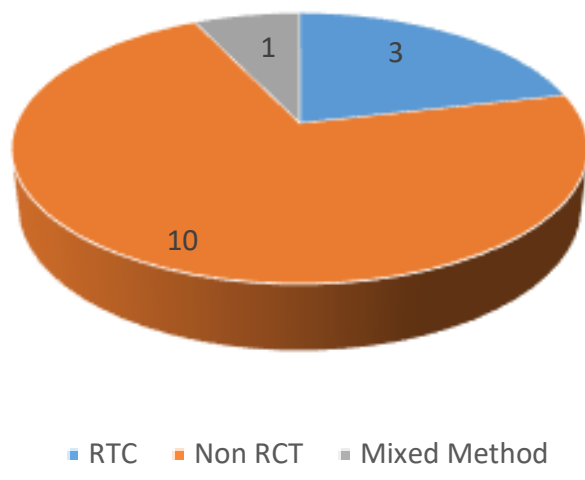

Gambar 3. Analisis berdasarkan Jenis Studi

3.1.3 Karakteristik studi berdasarkan kualitas/ grade

Setiap metode penelitian yang didapatkan mempunyai checklist Critical Appraisal yang tidak sama. Artikel yang sudah dipilih dan telah sesuai dengan kualitas yang terbaik 
yaitu artikel dengan grade A sebanyak 10 artikel yaitu pada artikel A1, A3, A4, A5, A6, A7, A10, A11, A13 dan A14. Artikel dengan grade B sebanyak 4 artikel yaitu pada artikel A2, A8, A9 dan A12. Pada penelitian yang didapatkan tidak ada artikel pada grade C.

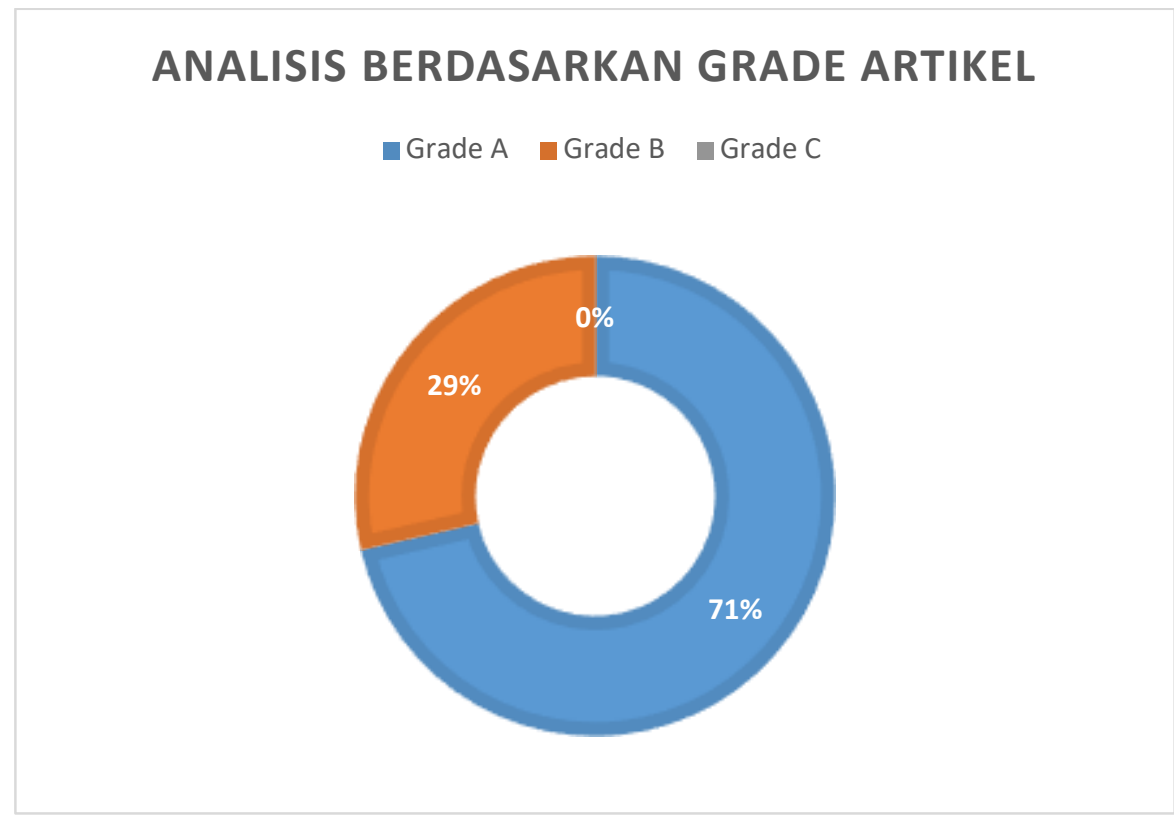

3.2. Tema

Gambar 4. Analisis Berdasarkan Grade Artikel

Tahap selanjutnya setelah melakukan analisis data, kemudian dilakukan pemetaan tema penelitian dari artikel yang sudah dipilih dengan membuat kategori menjadi 4 tema yaitu :

Tabel 5. Pemetaan Tema Artikel

\begin{tabular}{|l|l|l|}
\hline \multicolumn{1}{|c|}{ Tema } & \multicolumn{1}{|c|}{ Sub Tema } & \multicolumn{1}{c|}{ Artikel } \\
\hline $\begin{array}{l}\text { Faktor Pengaruh } \\
\text { Keberhasilan terapi } \\
\text { massage counterpressure }\end{array}$ & $\begin{array}{l}\text { a. Faktor internal } \\
\text { b. Faktor eksternal }\end{array}$ & $\begin{array}{l}\text { a. A4, A12 } \\
\text { b. A4, A12 }\end{array}$ \\
\hline $\begin{array}{l}\text { Efektifitas terapi massage } \\
\text { counterpressure }\end{array}$ & Tingkat keberhasilan & $\begin{array}{l}\text { A1, A3, A4, A5, A6, A7, A8, } \\
\text { A9, A10, A13, A14 }\end{array}$ \\
\hline $\begin{array}{l}\text { Tehnik terapi massage } \\
\text { counterpressure }\end{array}$ & $\begin{array}{l}\text { a. Tujuan teknik } \\
\text { massage counter } \\
\text { pressure } \\
\text { beknik } \\
\text { counterpressure }\end{array}$ & $\begin{array}{l}\text { a. A1, A3, A8 } \\
\text { b.A2, A4, A5, A9, A10, A12 }\end{array}$ \\
\hline $\begin{array}{l}\text { Hambatan terapi massage } \\
\text { counterpressure }\end{array}$ & Hambatan terapi & A7 \\
\hline
\end{tabular}

3.2.1 Faktor Pengaruh Keberhasilan terapi massage counterpressure

Pada artikel 14, ibu yang dilakukan terapi Massage counter pressure tetapi masih merasakan nyeri, hal ini disebabkan karena faktor pengalaman yang kurang baik pada persalinannya yang lalu. Hal ini juga dapat menambah rasa cemas, selain itu kepribadian yang dimiliki ibu mempunyai peran penting terhadap rasa sakit yang dirasakannya. Ibu yang mengalami rasa tegang dan cemas secara alamiah akan lebih lama mengalami stress dibandingkan dengan ibu yang tidak cemas dan percaya diri. Seorang ibu yang sudah kelelahan selama proses persalinan sebelumnya dan mengalami gangguan tidur karena 
ketidaknyamanan yang dirasakan mulai dari masa akhir kehamilannya, merasa kurang mampu mengatasi rasa sakit yang dirasakan. Responden dengan tingkat nyeri tanpa ada perubahan dari sebelum dan setelah tindakan counterpressure hal ini kemungkinan bisa disebabkan karena ada beberapa faktor yang tidak masuk dalam penelitian ini (14).

Artikel 12 menyampaikan bahwa terjadinya penurunan tingkat nyeri dapat dipengaruhi oleh kondisi lingkungan, ruangan. Masukan untuk penelitian selanjutnya supaya mendapatkan hasil yang maksimal dalam melakukan penelitian tentang massage counterpressure selain peneliti harus kompeten dalam pemberian perlakuan, selain itu persiapan lingkungan yang perlu dilakukan juga seperti ruangan yang dapat membuat ibu nyaman, tidak berisik dan harus didampingi oleh keluarga (15). Hal ini serupa dengan artikel 4, Adanya sarana dan dukungan yang baik dari lingkungan dalam upaya mengatasi nyeri, misalnya dukungan dari keluarga dan orang terdekat atau suami, hal ini sangat membantu dalam mengurangi rasa nyeri yang dirasakan ibu dalam persalinannya. Dukungan ini dapat berupa pujian, penentraman hati, tindakan untuk meningkatkan kenyamanan ibu, kontak fisik, informasi tentang persalinan dan kelahiran serta sikap ramah dapat mengalihkan perhatian ibu ,selama ibu merasa percaya diri bahwa ia akan menerima pertolongan dan dukungan yang diperlukan serta yakin bahwa persalinannya akan berjalan normal (16).

\subsubsection{Efektifitas terapi massage counterpressure}

Berdasarkan artikel 1, mengenai efektifitas teknik counterpressure di RSUD Tidar Magelang, rata-rata tingkat nyeri persalinan ibu yang tidak diberikan pijat counterpressure sebesar 6,6 lebih besar dari ibu yang diberikan pijat counterpressure dengan rata-rata sebesar 4,3 sehingga dapat disimpulkan bahwa ibu yang tidak diberikan pijat counterpressure mengalami rata rasa nyeri lebih tinggi (17). Hal ini sesuai dengan artikel 8, bahwa Efektifitas Counterpressure Terhadap Penurunan Intensitas Nyeri Kala I Fase Aktif Persalinan Normal Di Rumah Sakit Advent Manado" sebelum dilakukan counterpressure yaitu semua responden berada pada nyeri sangat berat dan setelah dilakukan counterpressure nyeri yang dirasakan menurun menjadi nyeri berat dan nyeri sedang sehingga dapat diketahui bahwa masase counterpressure efektif dapat menurunkan intensitas nyeri kala I fase aktif persalinan normal (18). Dijelaskan juga pada artikel 5, bahwa hasil untuk kelompok tingkat nyeri persalinan setelah dilakukan counterpressure mayoritas responden berada pada skala nyeri sedang (4-6) sebanyak 16 responden (61,5\%). Dengan demikian teknik counterpressure efektif dapat mengurangi nyeri persalinan pada kala I (19).

Pada hasil penelitian artikel 9 menjelaskan bahwa adanya penurunan tingkat nyeri pada satu grup yang dilakukan terapi massage counterpressure. Hal ini disebabkan karena pemberian massage counterpressure bekerja dengan cara saraf A-beta mendominasi transmisi serabut A-delta dan $C$ yang berdiameter kecil, sehingga dapat menurunkan aliran rasa nyeri yang melewati serabut A-delta dan $\mathrm{C}$ dengan cara memblok sinaps kesubstansigelatinosa untuk menghambat transmisi impuls nyeri. Terapi massage ini membantu ibu merasa lebih rileks, dan nyaman dalam persalinan (20). Artikel 10 memperoleh nilai mean tentang intesitas nyeri sebelum dan setelah dilakukan terapi massagae counter turun menjadi 5,4. Walaupun anggapan rasa nyeri dalam persalinan berbeda-beda pada ibu, tetapi ada suatu dasar fisiologis terhadap rasa nyeri selama persalinan. Hasil dari penelitian ini menjelaskan bahwa massage counter dapat menurunkan intensitas nyeri dalam persalinan. Selain dilihat dari nilai mean hasil ini diperkuat dengan hasil analisis data dengan menggunakan One Sample T-test yang diperoleh nilai sig sebesar 0,000, hal ini semakin menegaskan bahwa ada efektivitas dari perlakuan massage counter terhadap penurunan intensitas nyeri pada persalinan kala I fase aktif(21). Pada artikel 13 dijelakan, Penelitian ini menunjukkan bahwa menerapkan akupresur pada titik GB21 efektif dalam menghilangkan nyeri persalinan. Tidak ada efeksamping ibu dan neonatus yang diamati. Akibatnya, akupresur pada GB21 dapat diterapkan sebagai metode yang aman dan efektif selama persalinan untuk mengelola rasa sakit persalinan secara efektif. 
Diperlukan lebih banyak penelitian untuk membandingkan efektivitas akupresur satu bahu atau dua bahu (22).

\subsubsection{Tehnik terapi massage counter pressure}

Menurut artikel 2, Tehnik penekanan pada massage counterpressure diberikan dengan gerakan lurus atau lingkaran kecil. Menurut pakar massage, tehnik massage counter dapat membantu menurunkan skala nyeri persalinan yang dirasakan ibu saat dalam persalinan. Teknik massage counter yang dilakukan dengan pijatan dibagian lumbal memberikan rasa rileks sehingga mampu mengurangi ketegangan karena adanya pelepasan hormone endhorpin yang mampu mengurangi rasa nyeri(23). Artikel 3 menjelaskan bahwa Tehnik counterpreusure pada penelitian tersebut dilakukan dengan memberikan tekanan yang terus menerus selama kontraksi pada tulang sacrum ibu menggunakan kepalan salah satu tangan (24).

Terapi massage counterpressure ini hampir sama dengan terapi akupressure. Penggunaan akupressure pada titik SP6 adalah metode pelengkap yang non-invasif dan bisa meringankan rasa sakit selama persalinan, hal ini dijelaskan pada artikel 6 (25). Teknik acupressure point for locatation dilakukan dengan cara memberikan tekanan pada titik-titik tertentu pada jari-jari tangan, lengan, pergelangan, dan kaki sebagai upaya untuk menstimulasi dan merangsang meridian yang meningkatkan energi "qi" (energi kehidupan bagi orang Cina Kuno) sehingga diharapkan tubuh ibu akan memberikan respon fisiologis dan perbaikan dengan meningkatkan sirkulasi darah dan nyeri persalinan dapat diminimalisir, hal ini dijelaskan pada artikel 11(26).

\subsubsection{Hambatan terapi massage counter pressure}

Pemberian terapi massage counterpressure dalam mengurangi rasa nyeri persalinan pada pelaksanaannya ada beberapa hambatan yang dapat mempengaruhi hasil terapi tersebut. Hal ini disebabkan karena setiap orang dalam menyikapi nyeri berbeda-beda. Individu dengan kadar endorphin tinggi akan sedikit merasakan nyeri dibandingkan dengan yang memiliki sedikit/rendahnya kadar endorphin maka nyeri yang dirasakan sangat besar. Hal lain yang menyebabkan ibu primigravida tidak bisa beradaptasi dengan nyeri adalah berdasarkan pengalaman masa lalu, pola koping yang mal adaptif serta dukungan yang kurang dari keluarga. Hal ini dijelaskan pada artikel 7 (27).

\section{Kesimpulan}

Sesuai dengan tujuan penelitian yaitu untuk mengetahui pengaruh terapi massage counterpressure terhadap pengurangan nyeri dalam persalinan, maka dapat disimpulkan bahwa Terapi massage counterpressure dapat mengurangi rasa nyeri dengan intensitas tinggi dan memberikan rasa tenang dan senang sehingga dapat melawan rasa nyeri dalam persalinan pada saat merasakan kontraksi atau di antara kontraksi. Dengan adanya penurunan skala nyeri persalinan disimpulkan bahwa terapi dengan teknik counterpressure bisa dilakukan pada ibu dalam persalinan di kala 1 fase aktif, sehingga dapat membantu ibu dalam melewati proses persalinannya dengan nyaman. Meskipun dalam pelaksanaan pemberian terapi ini ada beberapa hambatan, salah satunya karena setiap orang dalam menyikapi nyeri berbeda-beda. Individu dengan kadar endorphin tinggi akan sedikit merasakan nyeri dibandingkan dengan yang memiliki sedikit atau rendahnya kadar endorphin maka nyeri yang dirasakan sangat besar.

\section{Ucapan Terimakasih}

Penulis berterimakasih kepada Magister Kebidanan, Fakultas Ilmu Kesehatan, Unisa Yogyakarta yang telah memfasilitasi studi ini. 


\section{Konflik Kepentingan}

Penulis menyatakan bahwa artikel ini tidak ada konflik kepentingan.

\section{References}

(1)Darmayanti, \& Suhrawardi. (2019). Counter Pressure Efektif Mengurangi Nyeri Persalinan ( Effectively of Counterpressure Reduce Labor Pain ). Caring Nursing Journal, 3(1), 16.

(2)Vaira, R., Yanti, \& Hidayat, A. (2020). A qualitative study of partnership between woman and midwife within midwife-led care clinic | Vaira | Journal of Health Technology Assessment

inMidwifery.https://ejournal.unisayogya.ac.id/ejournal/index.php/JHTAM/article/vi ew/1368/pdf

(3)Farida, S., \& Sulistiyanti, A. (2019). Metode Counterpressure Sebagai Upaya Untuk Mengurangi Nyeri Persalinan Kala I. Smiknas, 217-222.

(4)Fitri, N., Nadia Emilda, D., Kesehatan, F., Fort De Kock, U., \& Barat Indonesia, S. (2020). Perbandingan Massage Counterpressure Dan Massage Counter Pressure Menggunakan Minyak Esensial Lavender Terhadap Tingkat Nyeri Persalinan Kala I Fase Aktif. Maternal Child Health Care Journal, 2(3).

(5)Gonenc, I. M., \& Terzioğlu, F. (2020). Effects of massage and acupressure on relieving labor pain, reducing labor time, and increasing delivery satisfaction. Journal of Nursing Research, 28(1), 1-9. https://doi.org/10.1097/jnr.0000000000000344

(6)Karuniawati, B. (2019). Efektivitas Massage Counter Dalam Menurunkan Intensitas Nyeri Persalinan Kala I. Jurnal Kesehatan Madani Medika, 10(2), 69-75. https://doi.org/10.36569/jmm.v10i2.63

(7)Mafetoni, R. R., \& Shimo, A. K. K. (2016). Efeitos da acupressão sobre a dor no trabalho de parto: Ensaio clínico randomizado. Revista Latino-Americana de Enfermagem, 24. https://doi.org/10.1590/1518-8345.0739.2738

(8)Oka, I. (2017). PENGARUH PEMBERIAN TEKNIK COUNTERPRESSURE TERHADAP PENURUNAN INTENSITAS NYERI PADA KALA I PERSALINAN. 07(09), 91-96.

(9)Rilyani, Arianti, L., \& Wiagi. (2017). Pengaruh Counter Pressure Terhadap Skala Nyeri Persalinan Di Rumah. Jurnal Kesehatan Holistik, 11(4), 257-264.

(10)Satria, M. (2018). Pengaruh Sebelum Dan Sesudah Dilakukan Pijat Punggung Teknik Conterpressure Terhadap Pengurangan Rasa Nyeri Ibu Bersalin Kala I Fase Aktif Di klinik bidan elviana. Menara Ilmu, XII(5), 85-92.

(11)Torkiyan, H., Sedigh Mobarakabadi, S., Heshmat, R., Khajavi, A., \& Ozgoli, G. (2021). The effect of GB21 acupressure on pain intensity in the first stage of labor in primiparous women: A randomized controlled trial. Complementary Therapies in Medicine, 58, 102683. https://doi.org/10.1016/j.ctim.2021.102683

(12)Yulianingsih, E., Surya, H., \& Suwarni, P. (2019). Teknik Massage Counterpressure terhadap Penurunan Intensitas Nyeri Kala l Fase Aktif pada Ibu Bersalin di RSUD. Dr. M. M Dunda Limboto. 17(2), 231-242.

(13)Hong, Q., Pluye, P., Fàbregues, S., Bartlett, G., Boardman, F., Cargo, M., Dagenais, P., Gagnon, M.-P., Griffiths, F., Nicolau, B., Rousseau, M.-C., \&Vedel, I. (2018). Mixed Methods Appraisal Tool (MMAT), Version 2018. User guide. McGill, 1-11.

(14)Darmayanti, \&Suhrawardi. (2019). Counter Pressure EfektifMengurangi Nyeri Persalinan( Effectively of Counterpressure Reduce Labor Pain ). Caring Nursing Journal, 3(1), 1-6. https://journal.umbjm.ac.id/index.php/caring-nursing

(15)Fitri, N., Nadia Emilda, D., Kesehatan, F., Fort De Kock, U., \& Barat Indonesia, S. (2020). Perbandingan Massage Counterpressure Dan Massage Counter Pressure 
MenggunakanMinyakEsensial Lavender Terhadap Tingkat Nyeri Persalinan Kala I FaseAktif. Maternal Child Health Care Journal, 2(3).

(16)Rilyani, Arianti, L., \&Wiagi. (2017). Pengaruh Counter Pressure Terhadap Skala Nyeri Persalinan Di Rumah. JurnalKesehatanHolistik, 11(4), 257-264.

(17)Yulianingsih, E., Surya, H., \&Suwarni, P. (2019). Teknik Massage Counterpressure terhadapPenurunanIntensitas Nyeri Kala l FaseAktif

(18)Oka, I. (2017). PENGARUH PEMBERIAN TEKNIK COUNTERPRESSURE TERHADAP PENURUNAN INTENSITAS NYERI PADA KALA I PERSALINAN. 07(09), 91-96.

(19) Farida, S., \&Sulistiyanti, A. (2019). Metode Counterpressure SebagaiUpayaUntukMengurangi Nyeri Persalinan Kala I. Smiknas, 217-222.

(20)Budiarti, A. (2020). Pengaruh Terapi Massage Counterpressure Terhadap Nyeri Kala I Pada Ibu Inpartu Di BPS Desa Durjan, Bangkalan. Jurnal Ilmu Keperawatan Maternitas, 3(1), 14. https://doi.org/10.32584/jikm.v3i1.79

(21)Fitiawati, L. (2020). Perbedaan Tingkat Nyeri Persalinan Sebelum dan Sesudah Terapi Acupressure Poit for Lacatation pada Ibu Bersalin Kala I di Rumah Sakit Jember Klinik Kabupaten Jember. Skripsi.

(22)Irawan, D. (2020). Pengaruh Counter Pressure Terhadap Penurunan Nyeri Persalinan Kala I Sytematic Review. 2507(February), 1-9.

(23)Salakory, J. A. (2018). Perbedaan Teknik Back Deep Massage Dan Firm Counter Pressure Terhadap Nyeri Ibu Inpartu Kala I Fase Aktif Di Kamar Bersalin Rumah Sakit Umum Daerah Dr. M. Haulussy Ambon. Global Health Science, 3(4), 339-345.

(24)Torkiyan, H., SedighMobarakabadi, S., Heshmat, R., Khajavi, A., \&Ozgoli, G. (2021). The effect of GB21 acupressure on pain intensity in the first stage of labor in primiparous women: A randomized controlled trial. Complementary Therapies in Medicine, 58, 102683. https://doi.org/10.1016/j.ctim.2021.102683

(25)Karuniawati, B. (2019). Efektivitas Massage Counter DalamMenurunkanIntensitas Nyeri Persalinan Kala I. JurnalKesehatanMadaniMedika, 10(2), 69-75. https://doi.org/10.36569/jmm.v10i2.63

(26)Satria, M. (2018). PengaruhSebelum Dan SesudahDilakukanPijatPunggung Teknik ConterpressureTerhadapPengurangan Rasa Nyeri IbuBersalin Kala I FaseAktif Di klinikbidanelviana. Menara Ilmu, XII(5), 85-9217. Gönenç, I. M., \&Terzioǧlu, F. (2020). Effects of massage and acupressure on relieving labor pain, reducing labor time, and increasing delivery satisfaction. Journal of Nursing Research, 28(1), 1-9. https://doi.org/10.1097/jnr.0000000000000344

(27)Mafetoni, R. R., \&Shimo, A. K. K. (2016). Efeitos da acupressãosobre a dor no trabalho de parto: ensaioclínicorandomizado. Revista Latino-Americana de Enfermagem, 24. https://doi.org/10.1590/1518-8345.0739.2738.

(28)Gonenc, I. M., \&Terzioglu, F. (2020). Effects of massage and acupressure on relieving labor pain, reducing labor time, and increasing delivery satisfaction. Journal of Nursing Research, 28(1), 1-9. https://doi.org/10.1097/jnr.0000000000000344 